\title{
Corporate Governance as a School of Social Reform
}

\section{Ciarán O'Kelly*}

\section{INTRODUCTION}

In this paper, I present a vision of the corporation as a moral person. I point to "the separation of ownership and control" as a moment when the corporation broke away from the moral lives of ownermanagers. I then draw out the manner in which we can speak of the company as a moral person. Finally, through a discussion of social reporting in two British banks, I point to a shift in how this moral personhood is articulated, with the rise of corporate governance-or doing business well - as its own foundation of corporate responsibility. I propose a view of corporate responsibility as a "transmission mechanism" for the company's role in moral life, situated in the broader social conception of "moral economy." 2 This viewpoint sets out landscapes of legitimation and justification through which the ties that underpin economic life are founded.

\section{THE MORAL ECONOMIES OF CAPITALISM}

The company - as it was first encountered during the Industrial Revolution - was often regarded as destabilizing and subverting established social norms. Politicians expressed concern about disruption of the family and the domestic sphere caused by industrialization, and so they sought reforms aimed at restoring the domestic sphere as a moral center

\footnotetext{
* Queen's University Belfast School of Law. Ph.D., Reading University. I can be reached at c.okelly@qub.ac.uk.

1. The separation of ownership and control refers to the emergence of a managerial class associated with, but not identical to, an unconcentrated shareholding population. ADOLF BerLE \& Gardiner MeAns, The Modern Corporation AND Private Property ch. 1 (1932).

2. Moral economy refers to discourses regarding the relationship between prevailing norms of fairness and the broad facts of economic distribution. E. P. THOMPSON, THE MORAL ECONOMY OF the English Crowd in the EighteEnth Century, Past \& Present 76 (1971); see, e.g., JameS SCOTT, The Moral ECONOMy OF THE PEASAnT (1976).
} 
in people's lives. ${ }^{3}$ In fictional accounts from the period, redemption for owner-managers was held to be available through encounters with domestic life. ${ }^{4}$

The moral transformation of Mr. Thornton in Elizabeth Gaskell's North and South sets out an instructive picture of the link between industrial capitalism and the capitalist in this era. Gaskell's portrayal of "powerful and invisible social processes in visible forms" is instructive for this paper's purpose. Her narrative serves as an account of the wavering line between public and private in industrial capitalism. It also gives the reader a good reference point with which to set out the distinct character of the company cast free of the capitalist.

Gaskell, who "writes in a city in which industrial production and a dominant market are the determining features, and in which . . . there is the new hard language of class against class," the town of Milton, based on her native Manchester. Milton is experienced through the eyes of Margaret Hale, who witnesses the town as riven with class conflict, especially as expressed in struggles between $\mathrm{Mr}$. Thornton, a mill owner and manager, and Mr. Higgins, a worker.

In the early stages of the novel, Mr. Thornton is portrayed as viewing his responsibilities toward his workers as purely formal and procedural. He regards himself as a "benign despot," ruling over his "hands" in the mill and having no regard for them beyond the factory gates. ${ }^{7}$ North and South turns in large part on the shifts in Mr. Thornton's feelings, not toward the workforce so much as toward his own sense of how production, management, and responsibilities all interrelate.

Mr. Thornton finds redemption in his encounters with domesticity through the family lives of the Hales and of Mr. Higgins. Over the course of the novel, Mr. Thornton is redeemed by his encounters with the domestic sphere. He is brought to a point where he devotes attention to the welfare of workers, sees them as human beings rather than as hands, and expresses a wish to engage them in cooperative "discourse . . . beyond the cash nexus," ${ }^{8}$ including sharing meals and plans with them. "The pri-

3. See Timothy L. Alborn, The Moral of the Failed Bank, 38 VICTORIAN STUD. 199 (1995).

4. See CAtherine Gallagher, The Industrial Reformation of English Fiction (1988).

5. Andrew H. Miller, Subjectivity Ltd: The Discourse of Liability in the Joint Stock Companies Act of 1856 and Gaskell's Cranford, 61 ENG. LiTERARY HiST. 139, 141 (1994) (commenting on Dickens).

6. RAYMOND WiLliams, THE COUNTRY AND THE CITY 219 (1973).

7. Elizabeth Gaskell, NORTh AND SOUth 118 (1855). Gaskell's plot turns on similar themes to those found in CHARLES DiCKENS, HARD TIMES (Longman 2003) (1854).

8. GASKELL, supra note 7, at 420. For a discussion of the idea of the "cash nexus," see THOMPSON, supra note 2 , at 79 . 
vate solution in North and South," Catherine Gallagher writes, "does not entail a retreat from social responsibility; rather, it is a solution that clears away practical barriers to social harmony." In other words, class conflict is resolved in the novel because contractual relations transform into friendships.

In the narrative, redemption comes through attention to the perspectives of others and to a new sense of responsibility that dissolves Mr. Thornton's sense of a divide between his private and public selves. His renewed responsibility emerges from the domestic, private sphere, which acts as a "school of social reform." 10 Thus, capitalism was redeemed through reform of the owner-manager himself. The "cash-nexus" of production was not imagined as necessarily remote and separate from the notional private realm. Though not fully integrated with it, it was dependent upon it: the moral life of capitalism was the moral life of the capitalist.

The subsequent separation of ownership and control that emerges with the switch from owner-manager capitalism to shareholder capitalism connoted the company as "hollowed out" with regard to its relationship to individual moral agency. Companies, as they emerge with shareholder capitalism, are "often seen as rather malleable, as empty or half empty vessels into which different contents can be poured; entities whose direction and behaviour are determined, as it were, from the outsidefrom who controls them - rather than from within."11 As Paddy Ireland points out, the managerial theories of the mid-twentieth century and more recent stakeholder models are inspired by this "hollowing out" to advocate corporate governance models that license orientations beyond the shareholder. ${ }^{12}$

Beyond that, the mainstream finance-based Anglo-American model of corporate governance, ${ }^{13}$ which views the company as a series of multilevel markets for contract generation and contract management, holds to a similar hollowing out thesis. But in this model, the company is less an articulation of the board's will and more a series of signals to markets.

9. GALLAGHER, supra note 4, at 177.

10. Id. at 115 .

11. Paddy Ireland, Capitalism Without the Capitalist, 17 J. LEGAL HIST. 41, 69 (1996).

12. Id.

13. See Frank Easterbrook \& Daniel Fischel, The ECONOMiC Structure of Corporate LAW (1991); Reinier KraAkMAN ET AL., The ANATOMy of Corporate Law: A COMPARATIVE AND FunCTIONAL APPROACH (2009); Henry Hansmann \& Reinier H. Kraakman, The End of History for Corporate Law, 89 GEO. L.J. 439 (2001); Michael C. Jensen \& William H. Meckling, Theory of the Firm, 3 J. FIN. ECON. 305 (1976); Michael C. Jensen, Value Maximization, Stakeholder Theory, and the Corporate Objective Function, 22 J. APPLIED CORP. FIN. 32 (2010). 
The standard thesis is similar to the managerial and stakeholder positions Ireland outlines in that it assumes corporate personality to have dissipated with the separation of ownership and control. For Ireland himself, the company is a "personification of industrial capital" and is subject to the "relentless logic" $" 14$ of capitalism in its behavior and form. What is missing in all these hollowing out perspectives is the kind of definite moral anchor for corporate conduct that was held to exist when corporate and individual conduct were more closely aligned. As I argue in the following sections, the corporation, floating free of individual moral personhood, creates a kind of moral personhood through narratives that seek to define and stabilize the firm's conduct and character. ${ }^{15}$

These narratives of moral personhood draw on the conventions of moral economy ${ }^{16}$ - struggles and conventions through which questions of distribution, desert, and economic order in society are debated and resolved - so as to lend internal coherence to the productive and disciplinary practices of the firm and to provide external context for corporate action. Furthermore, prevailing ideas of how the company and its purpose ought to be characterized act as transmission mechanisms that explain and mediate the company and wider market imperatives at work in society.

In analyzing the corporation's character narrative, a critical consideration is the concept of social responsibility and its role in articulating a public face for the corporation. I point to the manner in which responsibility narratives are aligned with wider norms and imperatives in the structure of the firm and as conceived through the ideological precepts of market-driven social reform.

The question of personhood is most useful in interrogating issues of corporate responsibility. It helps in understanding the company as a unified agent characterized by the production of moral narratives. But that is not to say that I see the company as intrinsically a person. The company is, rather, a fictional person, whose sense of intentionality and agency is generated from the narratives attached to it. Those narratives are themselves not intrinsic but are the product of negotiation and conflict over ambiguous resources, laws, and rules attached to economic production

14. Ireland, supra note 11 , at 69.

15. See Ciarán O'Kelly \& Melvin Dubnick, Power and the Ethics of Reform, in ETHICS IN Public Management (H. George Frederickson \& Richard K. Ghere eds., 2d ed. 2013) (discussing organizational ethics and the struggle to define the organizational purpose, albeit regarding the public sector).

16. For information on the concept of moral economy, see SCOTT, supra note 2; THOMPSON, supra note 2; William James Booth, On the Idea of the Moral Economy, 88 AM. POL. SCI. REV. 653 (1994). 
and the myths and conventions of social life to which those negotiations and conflicts refer. ${ }^{17}$ Personhood here is performative.

Through this lens, corporate responsibility is more than a strategic focus on corporate executives' "reputation, competitiveness[,] and riskmanagement." Instead, we should view corporate responsibility as an attempt to focus and define the company, to situate and personify itself as a set of "practices and institutions that surround the moral life," 19 and to explain itself in terms of ordinary moral life. The business case for moral responsibility, though important, is only half the picture. ${ }^{20}$ Corporate responsibility is a struggle to articulate a kind of moral standing inwardly toward the corporation as well as outwardly toward society at large. While I argue for a thicker sense of corporate responsibility through a discussion of personhood, I do not claim that that responsibility is necessarily radical or transformative. ${ }^{21}$ My claim, rather, is that corporate responsibility reflects an incessant desire to embed the company in ordinary moral life.

In the next part of the Article, I give an account of the company as a unified moral agent. Following the work of List and Pettit, ${ }^{22}$ I focus on the company's emergence through struggles to negotiate and define its practices and institutions through broader social myths and conventions. I discuss narratives and personhood, both in natural persons and in the company. I show how the shortcomings of the narrative self in natural persons actually make the concept more telling for companies. I point to

17. See John W. Meyer \& Brian Rowan, Institutionalized Organizations, 83 AM. J. Soc. 340 (1977); see also Lauren B. Edelman \& Mark C. Suchman, The Legal Environments of Organizations, 23 ANN. REV. Soc. 479 (1997) [hereinafter Edelman \& Suchman, Legal Environments]; Mark C. Suchman \& Lauren B. Edelman, Legal Rational Myths, 21 LAW \& SOC. INQUiRY 903 (1996) [hereinafter Suchman \& Edelman, Rational Myths].

18. DePartMent of TRAde AND Industry, Business AND SOCIETY: Developing Corporate Social ReSPONSIBILITY IN THE UK (2001) (U.K.); see Simon Deakin, Squaring the Circle? Shareholder Value and Corporate Social Responsibility in the U.K., 70 GEO. WASH. L. REV. 976, 985 (2002).

19. Terry Pinkard, Virtues, Morality and Sittlichkeit, 7 EUR. J. PHIL. 217, 226 (1999) (calling the emergence of such practices and institutions a "Sittlichkeit," that is, the set of "practices and institutions that surround the moral life").

20. See David Millon, Two Models of Corporate Social Responsibility, 46 WAKE FOREST L. Rev. 523 (2011); see also David J. Vogel, Is There a Market for Virtue?, 47 CAL. MgMT. Rev. 19 (2005).

21. See Ronen Shamir, Corporate Social Responsibility, 9 THEORETICAL INQUIRIES L. 371 (2008); Ronen Shamir, The De-Radicalization of Corporate Social Responsibility, 30 CRITICAL SOC. 669 (2004); see also Paddy Ireland \& Renginee G. Pillay, CSR and Changing Modes of Governance, in CORPORATE SOCIAL RESPONSIBILITY and REgulatory GOVERnANCE: TOWARDS INCLUSIVE DEVElopment? 77 (Peter Utting \& José Carlos Marques eds., 2009) [hereinafter CORPORATE SOCIAL RESPONSIBILITY].

22. Christian List \& Philip Pettit, Group Agency (2011). 
the manner in which the dynamics of corporate moral personhood act at the level of the economy as transmission mechanisms between society and market. In the part after that, I draw out some of the character of corporate responsibility through an analysis of corporate reports, focusing especially on HSBC and Barclays Bank in the U.K. I point to the shift in the company's moral narratives toward a conception of responsibility as doing business well.

\section{THE COMPANy AS A UNIFIED MORAL AgENT}

When it came to the kind of capitalist organization described by Gaskell, the moral character of the organization arose from its association with the capitalist. There was little sense of a distinctive corporate personhood in the terms I set out above because the company as a distinct entity was not fully realized. As a consequence, the company was also accessible to the moral predilections of capitalists. For instance, the religious senses of some manufacturers famously prompted them to pursue a less brutal - if more patriarchal - factory capitalism than they might otherwise have done. Taking one prominent example, urban spaces were constructed through the nineteenth and into the twentieth century with a view toward workers' welfare, broadly speaking. ${ }^{23}$ Social responsibility was, in these cases, not corporate, but personal. Owner-manager power-even if it was conceived in highly patriarchal terms - was not minimized through the imagined equality of contract, nor was it dismissed as beyond the capacities of capitalism.

The understanding of personalized capitalism upon which North and South sits is at odds from the capitalism that emerges with the separation of ownership and control. The potential for a more extensive partiality fades in the face of the emergence of the company as a standalone device. Whereas capitalism imagined in Victorian England was restored to society through the owner-manager, the separation of ownership and control sees the modern company cast adrift from capitalists.

After all, the separation of ownership and control implies the separation of individual moral sentiments from action in production. Managerial power is imagined as being put to the service of a passive shareholding body. This lends a twofold distance from moral reasoning over corporate actions when managers decline to follow their moral predilections.

23. For a discussion on Cadbury, see Charles Dellheim, The Creation of a Company Culture, 92 Am. Hist. ReV. 13 (1987); Charles Wilson, Economy and Society in Late Victorian Britain, 18 ECON. HIST. Rev. 183 (1965); see also David J. Jeremy, The Enlightened Paternalist in Action, 33 Bus. HIST. 58 (1991); Michael Rowlinson \& John Hassard, The Invention of Corporate Culture, 46 HuM. REL. 299 (1993). 
First, it creates distance from moral reasoning where those predilections conflict with their duties to the company's members. Second, shareholders cannot bring their moral reasoning to bear because they have very little control over the everyday actions of the company beyond those reserved for them in the articles of association. ${ }^{24}$

One might ask what the separation of ownership and control means for responsibility. Elizabeth Wolgost provides one possible answer: responsibility more or less disappears. ${ }^{25}$ I suggest a different tack, however. While it is true that the separation of ownership and control is also the separation of corporate action from individual moral sentiments, this does not necessarily mean that the company loses its moral content on the whole. Rather, the company is personified through the development of its own moral narrative.

My central claim is that narratives of responsibility are narratives of personhood. Much energy is expended on situating the company in a moral environment, providing a context through which it can be understood and explained, both internally and externally. Through this endeavor we see the emergence of the company as an unified and autonomous agent. Following List and Pettit, corporate personhood is performative: it suggests that "a person is an agent who can perform effectively in the space of obligations. $" 26$

So, I take personhood to relate to the performance of agency in a sphere of mutual obligations. I also see this performance-intentionality around the "presentation of a moral self" intense concern with the construction of a normative environment around which the firm coheres. Performative personhood occurs, on this level, in the eyes of others. Adam Smith states that

man naturally desires, not only to be loved, but to be lovely; or to be that thing which is the natural and proper object of love [and] he naturally dreads, not only to be hated, but to be hateful; or to be that thing which is the natural and proper object of hatred. ${ }^{28}$

24. See, e.g., Automatic Self-Cleansing Filter Syndicate Co. v. Cuninghame, [1906] 2 Ch. 34 (U.K.). The balance of power over action was established in large part by the beginning of the twentieth century, from that point on, shareholder decision making was limited to questions over the trade in shares rather than over the government of companies.

25. Elizabeth Wolgast, Ethics of AN ARTificial Person (1992).

26. LiST \& PETTIT, supra note 22, at 173. As such, I do not imbue the corporation with intrinsic personhood. Nor do I view the issue of personhood as a thin metaphorical matter, little more than useful shorthand for the purposes of contract management.

27. ERving GofFMan, The Presentation OF SELF IN EVERyday LifE (1969).

28. ADAM SMith, THE THEORY OF MORAL SENTIMENTS 132 (2002). 
If this is correct, then we should see the performance of moral selfhood - the situating of self in broad societal norms - as placing the company far beyond formal and procedural domains.

This is not to say that the performance of personhood is directly and explicitly a function of the company or its directing minds, though they are obviously powerful agents in any particular situation. The company's moral character does not exist as an institution fixed in its character, defined by law, and brought to markets ready-made. Rather, it emerges from an uncertain and contingent interplay of laws, rules, and conventions, and from the negotiation of and struggles over how those laws, rules, and conventions can be defined and applied.

This interplay is necessarily underpinned by a series of myths and "widespread understandings of social reality.", 29 Such myths emerge from and are acted upon by a myriad of social forces - not least, those arising from organizational persons negotiating and internalizing their own regulatory landscapes. ${ }^{30}$ As Suchman and Edelman have said about law in general, it is

actually a welter of conflicting principles, imperfect analogies, and ambiguous generalities. Thus, lawyers, judges, enforcers, and target populations negotiate the meaning of law in each application, seeking workable consensus rather than logical certainty.

Similar things might be said about the constitutional, contractual, and cultural forms that emerge through and are brought to bear upon the corporation. The law's regulatory landscapes, in the broadest sense, do not act upon social and corporate realities. They are constitutive of social and corporate realities. These landscapes do not act upon ready-made markets: they constitute the many markets - for products, for shares, for talent - through which the company is defined. A performative personhood emerges through these ambiguities, not least as an attempt to solidify and define a coherent corporate environment with the goal of directing and controlling the workforce and other aspects of production.

Thus, narratives surrounding the corporate form both evolve in accordance with wider myths and norms pertaining to capital and production - with questions of moral economy - and articulate the emergence of the corporate person through the shifting power structures of corporate governance. Of course, the character of the corporate person and its pres-

29. Meyer \& Rowan, supra note 17 , at 347.

30. See Lauren B. Edelman \& Mark C. Suchman, When the 'Haves' Hold Court, 33 LAW \& SOC'Y REV. 941 (1999).

31. Suchman \& Edelman, Rational Myths, supra note 17, at 932. 
ence in society is itself unstable because it tracks the shifting balances of power within corporations, and between corporations and other institutions and realms in social and economic life. ${ }^{32}$ It is within this context that we should see the company's moral personhood emerge.

Performative personhood is focused on the construction of moral narratives that provide a context for production. These narratives in turn rely on wider moral economy - struggles over the questions of distribution, desert, and hierarchy. The company - cast free of the capitalistcontinues to seek out a moral character. The corporate narrative of selfhood emerges from an attempt to situate the company in broader practices and institutions. More than that, however, the corporation actively constructs practices and institutions through its metrics-generation capacities, hierarchical structures, and social power. Without minimizing its own keying into existing conventions, the company, far more than any natural person, shapes the landscape within which it acts.

\section{NARRATIVES AND PERSONHOOD}

The idea of narrative selfhood has been invoked as a mode of understanding human moral life. Charles Taylor said the following with respect to the development of a sense of the good:

[It] has to be woven into my understanding of my life as an unfolding story. But this is to state another basic condition of making sense of ourselves, that we grasp our lives in a narrative. . . It has often been remarked that making sense of one's life as a story is also, like orientation to the good, not an optional extra; that our lives exist also in this space of questions, which only a coherent narrative can answer. In order to have a sense of who we are, we have to have a notion of how we have become, and of where we are going. ${ }^{33}$

Our moral lives, in other words, represent an important part of our constituting ourselves through the production of stories about our lives as a whole.

That said, in her discussion of narratives of selfhood (both factual and normative), Samantha Vice disputes the claim that "having a different self-conception from one that is narrative in form (assuming this is possible) is mistaken in a very significant way." ${ }^{34}$ She suggests that the "chancy and incomplete",35 character of human life is not well encom-

32. For a longer discussion, see Ciarán O'Kelly \& Sally Wheeler, Internalities and the Foundations of Corporate Governance, 21 SOC. \& LEG. S. 469 (2012).

33. Charles TAYlor, SOURCES OF THE Self 47 (1989).

34. Samantha Vice, Literature and the Narrative Self, 78 PHILOSOPHY 93, 94 (2003).

35. Id. at 107 . 
passed by the narrative form. In other words, while we are tempted to present ourselves in a story form, our lives as lived are more nuanced, more complicated, and quite often, more mundane than narratives allow. While we may turn to the narrative form in our autobiographical moments, for the most part, "we just live.",36

What Vice points out as a weakness in the "narrative self" metaphor - that its tidiness and artificiality do not map onto human life as it is in fact lived-is actually what makes the metaphor work when it is applied to the personhood of the firm. The inner life of the firm seems a perfect locus for the emergence of a narrative self. Contrary to standpoints in the finance-oriented and stakeholder traditions mentioned by Ireland - whereby the firm is hollowed out due to the separation of ownership and control - the company as it re-emerged is embodied by the production of narratives presenting itself to a multiplicity of observers. Floating free of the moral lives of capitalists has not left the company hollowed out. Rather, the company seeks to define and set out its moral landscape through the production of narratives of selfhood.

Narrative is crucial for thinking about the performative personhood of the company because, at base, the company acts as a narrativegenerating institution. The "practices and institutions" of moral life are defined and generated with reference to the "myths" and conventions of social life, ${ }^{37}$ but the company and its governance are distinctive in that the company explains itself as embedded in moral life.

The company's public face and its internal system of justifications are explanation all the way down, or more succinctly, they are a narrative. The company generates its own practices and institutions largely within the company but also beyond the company's bounds. Governance processes and procedures within the company, and the dynamics of admonition and approbation that are driven by them, all rely on the company manufacturing a normative environment through which action can be explained and from there structured and controlled.

Discipline cannot simply act through force. As Foucault points out, the normalization of discipline-rendering it invisible so that coercion becomes collaboration - is the most effective way to structure social institutions and the individuals who work within them. ${ }^{38}$ Without the manufacturing of explanatory narratives or production of "justificatory

36. Id. at 108 .

37. Meyer \& Rowan, supra note 17.

38. Michel FoucAult, Discipline AND Punish 187 (1979); see also John Roberts \& Robert W. Scapens, Accounting as Discipline, in CRITICAL AcCounTs 107 (David J. Cooper \& Trevor M. Hopper eds., 1990). 
truths, ${ }^{39}$ discipline simply becomes a site of conflict. However, by producing those narratives, internal work can be given purpose.

Governance processes are not disciplinary only in prohibitory terms. They are also acted out as licenses, defining and allocating both material and normative values throughout the organization. "An occupation," according to E. C. Hughes, "consists, in part, of a successful claim of some people to licence to carry out certain activities which others may not, and to do so in exchange for money, goods or services. ${ }^{, 40}$ And while the company is shaped in large part by the human society it draws on, ${ }^{41}$ it refines and enhances social norms toward corporate ends and then promotes and demotes in line with those norms. Corporate capitalism, in this sense, chooses its own virtues.

Similarly, beyond the company, the company and corporate governance are set out through corporate reports, a social-responsibility presence, and various signals to markets, policy makers, and other publics. Again, these external features are meaningless without some kind of normative content. The ambiguous, negotiated character of the compa$n y^{42}$ must be established in a manner that allows the company to cohere internally and to conduct itself (and control its environment) externally. This is the core of performative personhood.

This is not simply about the exercise of corporate power. The construction of a moral environment - through an interaction with forces within and without the firm-involves an effort to explain and negotiate the embeddedness of the company in the ordinary moral world, and simultaneously, to ground the various ways in which work within the company and corporate action can be set apart from "ordinary" moral life. The corporate environment on these terms is socially and institutionally educative.

\section{THE COMPANY AS A TRANSMISSION MECHANISM}

So, when we think of the company as "personifying capital," we should think of it as manufacturing and disseminating narratives that set out its place in the social environment and that justify its internal structures and wider social role. This brings us to one crucial issue arising

39. Richard Rorty, Philosophy AND the Mirror of NATURE 383 (1980) (speaking of "justificatory truths" as "the moral philosopher's special form of bad faith," whereby people present moral vocabularies as facts and seek to enforce standpoints as a result; for instance, the presentation of the company as a nexus of contracts is arguably just such a maneuver).

40. EVERETT CHERRINGTON Hughes, MEN AND THEIR WORK 78 (1958).

41. See Rosabeth Moss Kanter, Men and Women of the Corporation (rev. ed. 1993).

42. See Suchman \& Edelman, Rational Myths, supra note 17; see also Edelman \& Suchman, Legal Environments, supra note 17. 
from the narration of the company's moral life: broad ideas of the company shape conceptions of political economy. Prevailing ideas of the company act as transmission mechanisms, providing a moral context and grounding to the market economy.

Much has been written about the liberal and neoliberal claims on "self-ordering" 43 markets as free-standing "sites of truth" 44 where questions of justice have no place. For Polanyi, the utopian project to disembed market from society, although doomed for failure, presents a mortal risk to society as a whole ${ }^{45}$ as the spontaneous ordering mechanisms of markets are extended ever further into social life. The disruptive force of markets sees alternative social structures set aside if they cannot be reconfigured as subject to the account-making and value requirements of market orders. ${ }^{46}$ By this measure, markets are a standard of legibility against which society must be held. ${ }^{47}$

For most people, the corporation mediates more or less all interaction with market forces today. Our economic life, in other words, is a corporate life. It may be that this is experienced as the invocation and enforcement of supposedly iron market laws, shorn of moral content. This might not be the norm, however. Take the issue of employment and corporate downsizing: layoffs are often presented as inescapable products of market forces. This is articulated in more nuanced ways than would be suggested by the idea that the corporation treats market forces as a simple fait accompli.

Take for instance an admiring account of Jack Welch's downsizing scheme that reduced General Electric's workforce by close to 100,000 people during the 1980s:

Jack Welch countered that nothing - including one's job - could be considered sacred, and he had a forceful argument for this reasoning. Ultimately, all that mattered was the survival of the company. That was what counted most, not any particular job. He knew that his downsizing program would cause pain, a great deal of pain, yet it could not be helped. Not if General Electric was to survive and

43. 1 FRIEDRICH A. HAYEK, LAW, LEGISLATION AND LIBERTY 68-71 (1973).

44. Michel Foucault, The Birth of Biopolitics 31 (2008); see Ute Tellmann, Foucault and the Invisible Economy, 6 FoUCAULT STUD. 5 (2009) (providing an interesting account on the "invisible hand").

45. KARl Polanyi, THE GREAT TRANSFORMATION (1944).

46. On the disruption wreaked by markets, some scholars, even those scholars who agree with Hayek, have been given pause. See JoHn Gray, HAYEK ON LiBERTY (3d ed. 1998).

47. See James C. Scott, Seeing Like a State (1998); see also James C. Scott, Some Replies on Markets, Languages, and Law, CATO UnBound (Sept. 27, 2010), http://www.catounbound.org/2010/09/27/james-c-scott/some-replies-on-markets-languages-and-law/. 
flourish in a more competitive global arena. Welch was prepared to be stoic, though he admitted in later years that downsizing was the worst part of his job. ${ }^{48}$

This passage indicates a common position on the market - the "competitive global arena" - as a "site of truth." ${ }^{49}$ Nothing, it seems, is stable in the face of market pressures; jobs, and the allocation of capital that they embody, simply come and go. The company's survival and expansion is the key duty, and by implication the key facet of "leadership" is "all that matters." Such a narrative, in this particular example, allows Welch to both design and enforce a strategy that leads to job losses, and to simultaneously hold that the job losses, although regretful, are not morally attached to him. They are inevitabilities that "could not be helped."

This stance is emblematic of how the instrumental logic of capitalism is transmitted through the moral logic of corporate governance. It may be that the corporate officer, having caused these actions, suffers "agent-regret." 50 The officer wishes that these things had not come about. This is different, however, from believing that some other course was possible or that the corporate officer, though an agent, was an agent in a morally relevant fashion when he or she acted. Yet this is in itself a moral narrative. It focuses on ideas of duty and office that override other considerations. The narrative posits and explains corporate work as a special realm and license for action. While the roles inherent in corporate work involve action that is distinctive from "ordinary" moral life, these roles are connected to ordinary notions of duty and desert. ${ }^{51}$

The "new employment contract" 52 has seen the legitimation of corporate capitalism through job security replaced by legitimation through job satisfaction, which is another demonstration of the corporation working as a transmission mechanism between market and society. This relationship between organization, work, economic security, and career re-

48. Robert Slater, Jack Welch AND the GE Way 112 (1999).

49. FoUCAULT, supra note 44, at 31.

50. Bernard Williams, Moral Luck, 50 Proc. ARistotelian SoC’Y, SuPP. Vols. 115 (1976).

51. There is a substantial literature on "role moralities." See JuStin OAKLEY \& DEAN Cocking, ViRTUe EThics AND Professional Roles (2001); see also MARy Douglas, How InSTITUTIONS THINK (1987); WOLGAST, supra note 25. For a related and interesting discussion, see CHRISTINe SWANTON, Virtue Ethics, Role Ethics and Business Ethics, in WORKING VIRTUE: VIRTUE ETHICS AND CONTEMPORARY Moral PROBlems (Rebecca L. Walker \& Philip J. Ivanhoe eds., 2007).

52. David Thomas \& Monica Higgins, The Boundaryless Career: A New Employment Principle For a New Organizational ERA 268 (Michael B. Arthur \& Denise M Rousseau eds., 2001); Gary D. Kissler, The New Employment Contract, 33 Hum. Res. MgmT. 335 (1994). 
flects a profound shift in corporate capitalism's moral economy, through which questions about economic and social power distribution are matched discourse about fairness. ${ }^{53}$ Corporate commitments to workers' livelihoods, at least in the Anglo-American economic spheres, have been replaced by narratives and structures referring to the individual's responsibility - using opportunities provided by the corporate context - to develop their human capital. ${ }^{54}$ Corporations have not only incorporated "societally legitimated rationalised elements" $" 55$ into their structures, but have also driven the narratives that legitimate those elements. At least by the lights of this perspective, responsibility for careers has been handed over to individuals who are encouraged to develop their own paths through economic life.

Reference to market forces has involved more than a simple dismissal of qualms or queries through the invocation of the market as a "black box." Instead, we see an emphasis placed on virtues of duty and loyalty to the company. There is some evidence that this has been accompanied by broader shifts in attitudes toward corporate power, which accepts the place of market forces in economic life. Individuals may be responsive to such narratives in devising a sense of fairness relating to corporate layoffs. ${ }^{56}$ Given this, the corporate economy has, so far, been quite successful in concocting a moral language around markets, and in negotiating its own legitimacy, despite its dominant position over most people's lives and the evidence of layoffs' damaging effects. ${ }^{57}$

These narratives, often presented as "justificatory truths," "grow legs" 58 in an environment that takes those claims as both an explanation for current trends and as legitimation for those who benefit from those trends. The production of economic theory as the discovery of new truths is also the production of legitimatizing norms. Nonetheless, it is im-

53. ThOMpson, supra note 2; see also SteFFen MaU, The Moral ECONOMY of Welfare STATES (2003); SCOTT, supra note 2; Booth, supra note 16.

54. GARY StANLEy BeCKer, Human CAPITAL (1993); see also Jason Read, A Genealogy of Homo-Economicus: Neoliberalism and the Production of Subjectivity, 6 FoucAult StUD. 25 (2009).

55. Meyer \& Rowan, supra note 17 , at 352.

56. Gary Charness \& David I. Levine, When Are Layoffs Acceptable - Evidence from a QuasiExperiment, 53 INDUS. \& LAB. REL. REV. 381 (2000); Kevin F. Hallock, Layoffs in Large U.S. Firms from the Perspective of Senior Managers, 25 Res. Personnel \& Hum. Resources Mgmt. 137 (2006); Denise M. Rousseau \& K. Aquino, Fairness and Implied Contract Obligations in Job Terminations: The Role of Remedies, Social Accounts and Procedural Justice, 6 Hum. PERformance 135 (1993).

57. MARGARET M. Blair, OWNERShIP AND CONTROL 265 (1995).

58. Laureen Snider, The Sociology of Corporate Crime, 4 TheORETICAL CRiminology 169, 180 (2000). 
portant to note the role that the idea of the company plays in transmitting a moral vocabulary for market capitalism, not least because of its presence in both a series of market arenas and in "ordinary" society. ${ }^{59}$ This is not to say that the moral vocabularies of capitalism are made by the company as a pre-existing object; rather, they are performed and narrated through the company. Corporate personhood, emergent through the performance of a justificatory narrative, acts to explain the wider vicissitudes of capitalism in society. It re-embeds the economy in society's moral landscape.

The construction of practices and institutions - and through them the performative personhood of the firm - takes place almost solely through the narrative form. Whereas, as Vice says, natural persons "just live," firms present themselves and live through the stories they make because, ultimately, they are little more than stories - whether in terms of founding metrics and processes of admonition and approbation, or in terms of describing their own place in the world. The fictional person of the firm must rely on the form and format of fiction, through the production and placing of character in the world, in order to live. ${ }^{60}$

In this part, I have set out a substantial sense of corporate personhood as a narrative-based performance that both creates and is sustained by its own institutions and practices. Corporate personhood, by this light, is a pattern of justification, and this pattern, through processes of "legitimation and institutionalization," makes the firm appear as a "natural and meaningful," 61 wholly unified agent. ${ }^{62}$ The company, cast adrift of the capitalist, is still subject to, and seeks, efforts to define and sustain its place in the world. As I set out in the next section, narratives of corporate responsibility go to the heart of patterns of justification.

\section{THE EMERGENCE OF CORPORATE GOVERNANCE AS A SCHOOL OF SOCIAL REFORM}

The idea of the company's moral personhood and the role of the idea of the company as a transmission mechanism is seen to play out with regard to the rise of corporate governance itself - of doing business well - as a core dimension of social responsibility. As explained above, separated from the capitalist with the separation of ownership and control, the company was no longer in a position to avail itself of a mediated moral sense transmitted through the capitalist. So, as with Mr. Thornton

59. See KANTER, supra note 41.

60. Vice, supra note 34 , at 10.

61. Mark C. Suchman, Managing Legitimacy, 20 ACAD. MGMT. REV. 571, 576 (1995).

62. LIST \& PETTIT, supra note 22, at 31. 
in North and South, it was no longer possible to reform the corporation's presence in the world through individual redemption. There was no access to corporate reform through "schools of social reform" as individuals encountered. Cast adrift, the company has sought narrative ties through which it could be explained and personified. These ties, and the institutions from which they arise, tend to situate themselves in wider "myths" and "understandings of social reality.",63

In this part, I present a brief discussion of the switch to sustainability and citizenship, especially drawing on the corporate reporting of two financial institutions: Barclays Bank and HSBC. While the position of the financial sector is interesting because the current crisis is of its own making, Barclays is particularly interesting because of its recent invocation of citizenship narratives through its "Citizenship 2015" initiative. ${ }^{64}$ HSBC, as we see below, is interesting because its reports bear witness to a switch from a "gift-giving" to a "sustainability" mode.

The main aim of this part is to set out a sense of sustainability as a form of corporate personhood that reflects a particular sense of the corporate person as arising from market-driven social imperatives. Recall that corporate personhood, here, involves the productions of narratives that both explain and justify the corporation's place in society, and that also act as a transmission mechanism between market and society. It is the "personification of industrial capitalism," as Paddy Ireland had it, though not as a simple cipher; it personifies capitalism and moral economy by adopting many of the key aspects of moral personhood. ${ }^{65}$

\section{A. Gifts and Corporate Philanthropy}

Although there is a long-standing history of addressing corporate responsibility issues through ideas of citizenship, ${ }^{66}$ much of the corporation's actions are focused on corporate giving. While "the link between these gifts and the interests of shareholders was indirect," ${ }^{1,7}$ corporate giving, as the action driven by ideas of corporate responsibility, was usu-

63. Meyer \& Rowan, supra note 17 , at 347.

64. 2015 Citizenship Plan, BARCLAYS (Sept. 2012), http://reports.barclays.com/cr11/ourap proach/2015citizenshipplan.html? cat $=\mathrm{m}$.

65. Ireland, supra note 11, at 69.

66. See, e.g., Confederation of British Indus. Co. Affairs Comm., The Watkinson REPORT (1973); see also Archie B. Carroll, Corporate Social Responsibility, 38 Bus. SoC'Y 268 (1999) (outlining the evolving concept of corporate social responsibility).

67. DAVID Vogel, THE MARKeT For ViRTUE 18 (2005). 
ally performed in line with ideas of responsibility as reputation, competitiveness, and risk management. ${ }^{68}$

Alongside this, corporations allowed themselves to be recruited as collaborators in state-led regeneration projects. ${ }^{69}$ More recently, the United Kingdom has entered into effective partnerships with government in nonprofit academy schools and in constructing semipublic spaces around healthcare and entertainment. Banks have become involved in financial-literacy educational schemes and microfinance initiatives, which I discuss below.

While the gift-giving style of corporate social responsibility (CSR) is effective as a form of marketing and managing image and reputation, it has done little to integrate the company into society. Instead, it emphasizes corporate domination over people's lives. Gifts, as Marcel Mauss put it, are "total social phenomena" that bind giver and receiver in society. "[T] o refuse to give, to fail to invite, just as to refuse to accept, is tantamount to declaring war; it is to reject the bond of alliance and commonality." ${ }^{, 70}$ The receiver of the gift is not a simple beneficiary if the gift cannot be reciprocated. They must return the gift through obedience and respect for the giver's authority: they are in the giver's debt. ${ }^{71}$

The gift-giving style of CSR in parallel to this account rejects a conception of the company that sees it beyond the realm of "ordinary moral community." It stands outside the normal flows of moral community, seeking to legitimatize itself through the provision of patronage and gifts. Following Dinah Rajak's formulation, it is possible to see this style of CSR as being "characterised not by the Maussian ideal of mutual interdependence, but by deference and dependency in return for the patron's provision." 72 We should be cognizant of the fact that the quest for legitimation is, in itself, a sign of mutual dependency. ${ }^{73}$ Responsibility by these lights is a strategy: it is not characterized by a will to restore ordinary values to production.

The emergence of sustainability and citizenship narratives in these kinds of discussions around CSR is interesting here. As the Watkinson

68. DEPARTMENT OF TRADE AND INDUSTRY, supra note 18; Deakin, supra note 18, at 985; see Louis W. Fry et al., Corporate Contributions, 25 ACAD. MGMT. J. 94 (1982) (reviewing literature and grips with motivations behind giving from an American perspective); see also Archie B. Carroll \& Kareem M. Shabana, The Business Case for Corporate Social Responsibility, 12 InT'L J. MGMT REV. 85 (2010); Craig Smith, The New Corporate Philanthropy, 72 HARV. Bus. REV. 105 (1994).

69. See SALly WHEELER, CORPORATIONS AND THE THIRD WAY (2002).

70. MARCEL MAuss, THE GiFT 13 (2d ed. 1997).

71. See DAVID Graeber, DEBT: THE First 5000 Years (2011).

72. DINAH RAJAK, IN GOOD COMPANY 177 (2011).

73. See Suchman, supra note 61. 
report highlighted ${ }^{74}$ the alignment of social responsibility with corporate governance and a more expansive community involvement is not new. Nonetheless, the rise in corporate social reporting, and in the standalone social report in particular, has been paralleled by the rise of sustainability as a key norm in corporate narratives. I argue that this reflects a new, more cohesive personification of the company as social responsibility comes into line with market values.

The remainder of this part is divided into three sections. First, I discuss the rise of sustainability narratives in the corporate reports of Barclays and HSBC. Second, returning to the discussion of corporate personhood above, I suggest that sustainability narratives seek both to embed the company in the "ordinary" moral world. Finally, I discuss the manner in which the emergence of sustainability narratives as core ideas of corporate responsibility serves to transmit broad neoliberal norms by positing corporate governance as social responsibility in itself.

\section{B. Social-Responsibility Reports}

The rise of the standalone social-responsibility report has tended to coincide with the emergence of sustainability narratives and perhaps, just as importantly, with governmental, nongovernmental, and quasigovernmental partnership initiatives oriented toward CSR. ${ }^{75}$ Codes of conduct, such as the "Equator Principles" pact, ${ }^{77}$ are monitored and measured both by NGOs and by consultants in order to bring transparency to reports. To highlight their sustainability credentials, companies may collaborate and indeed compete over the top spot in responsibility indexes through organizations like Business in the Community. ${ }^{78}$

74. CONFEDERATION OF BRITISH INDUS. CO. AFFAIRS COMM., supra note 66.

75. See Tom Fox et Al., World BAnK, Public Sector Roles in Strengthening CORPORATE SOCIAL RESPONSIBILITY: A BASEline STUDY (2002), available at http://www.observatoritercersector.org/pdf/centre_recursos/3_4_fox_01345.pdf; SHARI NOURICK, Org. FOR ECON. CO-OPERATION \& DeV., CORPORATE SOCIAL RESPONSIBILITy: PARTNERS FOR Progress (2001); Daniel Arenas et al., The Role of NGOs in CSR, 88 J. BuS. ETHICS 175 (2009); Dima Jamali \& Tamar Keshishian, Uneasy Alliances, 84 J. Bus. ETHICS 277 (2008); Florence Palpacuer, Challenging Governance in Global Commodity Chains: The Case of Transnational Activist Campaigns for Better Working Conditions, in CORPORATE SOCIAL RESPONSIBILITY, supra note 21 , at 276.

76. EQUATOR PRINCIPLES, http://www.equator-principles.com/ (last visited Jan. 10, 2013) (governing the social and environmental impact associated with the financing of projects).

77. UNited NATIONS GLOBAL COMPACT, http://www.unglobalcompact.org/ (last visited Jan. 10, 2013)

78. BUSINESS IN THE COMMUNITY, http://www.bitc.org.uk/ (last visited Jan. 10, 2013); see also RAJAK, supra note 72 , at 29. 
The crucial switch in responsibility narratives is from the giftgiving accounts presented above and corporate governance-oriented narratives. While the switch often predates the adoption of standalone sustainability reporting, HSBC's report points to the juxtaposition between the two. Depending on what is included as a "gift," up to half of its 2000 report, HSBC in the Community: Sharing Our Success, ${ }^{79}$ is devoted to different kinds of gift-giving. These reports are focused on HSBC's priorities: education, inculcation of business and financial skills, and environment. Interestingly, in light of the new social contract, corporate responsibility is also attached to staff giving their time to projects, presumably facilitated by the company. thropic:

Sometimes the gift-giving seems more straightforwardly philan-

The Prem Dan Opportunity Centre in Mumbai (formerly Bombay) has given hope to thousands of children over the past 20 years. HSBC is supporting the founder, Sister Felicity, and her staff who currently teach vocational skills to more than 800 abused children in the centre's three purpose-built schools, as well as providing a home for them. ${ }^{80}$

In the United Kingdom,

HSBC's support for the Technology Colleges Trust, in particular for language colleges in underprivileged areas, continues to grow. Our investment in language education, particularly in Portuguese and Mandarin, not only reflects our international background, but highlights the need for greater international communication skills in the future. ${ }^{81}$

The list continues with gifts to the Wildlife and Wetlands Trust, mentoring programs employing HSBC staff in Buffalo, New York, ecology programs in New York City, and the like.

By the time the 2010 sustainability report came about, however, the gift-giving mode had almost entirely disappeared. Where it remains, it is sharply focused on environmental gifts involving staff donations of time and almost exclusively on financial education. ${ }^{82}$ The dominant themes of the 2010 sustainability report are on the company doing business well.

79. HSBC HOLDINGS, HSBC IN THE COMMUNITY: SHARING OUR SUCCESS (2000), available at http://www.csr-china.net/attach.aspx? $1=$ cn\&contentid=fcb0e728-e9b6-457d-9b21-961e8e322b8c\& count $=0$.

80. Id. at 4 .

81. Id. at 9 .

82. HSBC HOLDINGS, SUSTAINABILITY REPORT 2010 (2010), available at https://www.hsbc. com/1/PA_esf-ca-app-content/content/assets/sustainability/110526_sustainability_report_2010.pdf. 
So, its environmental credentials are set out either through its own efficiency programs, ${ }^{83}$ or through the provision of financial facilities and services to "climate business" and other commercial opportunities with an environmental aspect. ${ }^{84}$ The report focuses on attracting and "valuing" employees, treating customers well, paying taxes, and preventing financial crime. It addresses issues around the managing of environmental and other risks in order to "sustain" the business because "environmental and social risks can have a material impact on the financial success of our business and that of our customers." ${ }^{, 85}$ The report in general is rounded off with an assurance report from Price Waterhouse Coopers LLP, attesting to the veracity of the report. ${ }^{86}$

The journey between early and more recent reports is less stark in the case of Barclays Bank, whose reports across the decade have positioned it firmly in the "business case" camp when it comes to CSR. ${ }^{87}$ The Corporate Social Responsibility Report 2002: Making Business Sense, focused on four dimensions: CSR in the marketplace, the workplace, the community, and the environment. ${ }^{88}$

Roughly half the text in the 2002 report was devoted to CSR in the marketplace and in the workplace. In the discussion of CSR in the marketplace, the report focused on support for customers and businesses in deprived areas, including subsidizing credit to relatively high-risk businesses. The bank also pointed to its efforts to tackle financial exclusion, including making particular kinds of cards available to customers who might otherwise have been excluded, efforts on behalf of disabled customers, and efforts to address financial literacy problems. ${ }^{89}$

Regarding CSR in the workplace, the report focuses on a sequence of business and internal responsibility issues such as an account of the bank's "building a high-performance culture . . . to help employees fulfil their potential." 90 Specifically, the rewards and bonus schemes that encourage employees to perform, and the training programs that are required for staff to perform, reflect the bank's belief in its "duty to pro-

83. Id. at 18. At this stage, however, HSBC had abandoned a program to become and remain "carbon neutral" that had been running since 2006.

84. Id. at 10 .

85. Id. at 12 .

86. Id. at 23.

87. Jill Treanor, Barclays Publishes Three-Year Citizenship Plan, GUARDIAN Bus. Blog (May 23, 2012), http://www.guardian.co.uk/business/blog/2012/may/23/barclays-citizenship-banking.

88. BARClays, CORPORATE SOCIAL RESPONSIBILITY REPORT 2002: MAKING BUSINESS SENSE (2002), available at $\mathrm{http} / /$ group.barclays.com/about-barclays/citizenship/our-archive.

89. Id. at 4-6.

90. Id. at 6 . 
vide the professional and personal development opportunities vital to long-term employability and job satisfaction." " Combined with these issues is an account of the bank's engagement with trade unions through a partnership approach and its commitment to diversity among employees, to health and safety, including vis-à-vis HIV and AIDS, and to human rights through recruitment and labor practices.

Already, we can see tensions in the business case mode coming to the fore. While incentive schemes and health and safety practices in the workplace are either important components of corporate management or conventional aspects of performance management in the financial services industry, their role in social responsibility seems limited at best.

The 2002 CSR report saw Barclays's activities "in the community" focus on employee volunteering and on community investment, which was "channelled into five key areas: education, people with disabilities, social inclusion, the arts, and the environment." ${ }^{92}$ Regarding employee giving, corporate support mostly consisted of the donation of employee hours to support volunteering activities. In addition, the bank gave limited support to employees' fundraising efforts through a "pound for pound" program. The bank also facilitated employee giving through payroll processes. In all, roughly one third of Barclays's "in the community" support was in the form of direct donations, with two thirds coming from staff volunteering or giving. ${ }^{33}$

The role of CSR in the environment is deemed to involve two parallel concerns: first, the direct environmental impact of the corporate estate, travel, paper consumption, and the like; and second, indirect impacts through the business's functions. The Barclays report seeks to address both kinds of impact, outlining the bank's efforts to alleviate its direct environmental impact through the governance of resource usages, and its indirect impacts through adherence to the Equator Principles and through the general mainstreaming of environmental-risk awareness in its lending activities. Consider, for instance, the bank's environmental-riskmanagement unit (ERMU):

[It] continued to work with the Group's credit teams worldwide to raise their awareness of the environmental considerations to be factored into lending decisions. Screening of commercial land offered as loan collateral for potential contamination is a key component of the company's approach, and heightened awareness of this and oth-

91. Id. at 8 .

92. Id. at 10 .

93. It is open to argument exactly how credit for charitable efforts should be shared between a corporation facilitating somebody's efforts and the person making the effort himself. 
er environmental issues resulted in a $19 \%$ increase in the number of lending proposals referred to ERMU. ${ }^{94}$

How the approach to environmental awareness shifts across the decade is one of the issues at play in this Article.

The business case negotiates a very fine line between a position that "doing good for society can be good for business" and one that is more closely described as "business decisions that are socially beneficial," but that remain primarily as business decisions. As the report says, "[o]ur CSR activity is founded on financial performance. Strong financial performance provides a significant contribution to CSR in itself, but in addition it provides the foundation for greater aspiration and creativity in developing the CSR agenda." 95 I do not point to this mode of articulation as an invitation to cynicism or by way of acceptance of a Friedmanite orientation to profits. ${ }^{96}$ Rather, the degree to which social-responsibility reporting is presented as business initiative is itself quite interesting, especially as we see the character of Barclays's reports evolve through the 2000s.

When we get to the Barclays Citizenship Report in $2010,{ }^{97}$ the fourpart structure of the 2002 report has been left behind. In terms of substantive sections we are presented with three broad themes: "the way we do business," "contributing to growth," and "supporting our communities." Issues around giving, business management, and especially environmental responsibility are run through each section instead of being separated out.

What is most interesting, however, is that much of the report focuses on areas that are simply core business functions. For instance, six pages on "the way we do business" are devoted to compliance with regulatory requirements concerning fraud, money laundering, data protection, complaint-resolution governance, and customer satisfaction. Furthermore, while some of the environmental component is devoted to reporting on environmental-risk management in lending, this section also contains information on respect for human rights, respect for diversity, and health and safety management in the workplace. Much of this is related either to statutory requirements or simply to good business practices.

94. BARCLAYS, supra note 88 , at 12.

95. Id. at 6 .

96. Milton Friedman, The Social Responsibility of Business Is to Increase Its Profits, N.Y. TIMES MAG., Sept. 13, 1970, at 32.

97. BARCLAYS, CITIZENSHIP REPORT (2010), available at http://reports.barclays.com/ar10/ files/pdfs/barcar10_citizenshipreport.pdf. 
The section on Barclays's contribution to growth makes significant reference to Barclays's tax contribution and its support for the economy through lending, money advice, and environmental program investment. For example, attention is devoted to the leadership in carbon markets and social investment. The report states,

Investment managers at Barclays Wealth provide clients with opportunities to invest in specific environmental or social funds, as well as providing ethical screening for portfolios.

Barclays also offers clients a range of themed funds, including low carbon Venture Capital Trusts, Enterprise Investment Schemes and Exchange Traded Funds, which focus on clean energy, and socially responsible investment funds.

We are also one of the largest managers of charity assets in the UK with a dedicated team overseeing around $£ 2$ bn in assets under management for some of the UK's largest charities. ${ }^{98}$

Moving on to "supporting our communities," the report emphasizes that it provides support for young entrepreneurs, access to finance for people who would otherwise be excluded, and staff-giving programs. ${ }^{99}$ It also includes a report on environmental management, such as estate management. $^{100}$

\section{Interpreting the Reports}

For our purposes, what is most striking about Barclays's 2010 report is that around $15 \%$ of the text is devoted to issues that can only be seen as matters of corporate governance or of "doing business well." It is devoted to legal and regulatory compliance, contribution to growth through business activities, and similar goals. Beyond that, however, the report articulates a seemingly more traditional business case, reporting in a tone that is far more oriented toward the bank's business activities. Environmental-risk management, for instance, focuses as much on the production of environmental-risk-management products for sale as it does on assessment of other investments for environmental risks. The shift is crucial for our understanding of how social responsibility situates the company as a moral person.

Following Mauss, we might see the gift-giving responsibility mode, apparent in HSBC's 2000 report, as positioning the company as being

98. Id. at 57.

99. Id. at 60 .

100. Id. at 70 . 
somewhat outside society, situating it as dominant and powerful. The sustainability mode, perfected in more recent reports both from HSBC and Barclays, sees the company formulated less as a powerful actor donating resources to favored projects and clients, and more as an ordinary member of moral society. The imperatives produced by environmental concerns have been incorporated in a broader narrative of corporate governance in order to put forward an idea of the company as sustainable in the round: as a sustainable business, as an equal player in society's environmental project, and as an entity that is responsible simply by being itself well. The sustainability narrative, in short, has produced a ground in which a company can articulate itself as a moral end in itself-it is its own school of social reform.

That is, existing practices and institutions of corporate selfhood, focused on governance and employment satisfaction norms, have keyed into conventions surrounding environmental concerns, and have seen the company reinterpreted as negotiating and defining the meaning of sustainability in new ways. We ought not to see this as debasing the meaning of sustainability, but as reproducing corporate personhood-an attempt to produce a narrative that situates and lends coherence to the company, naming its place in society and giving purpose to its internal functions and work.

The metrics-based workings of sustainability narratives are themselves revealing. Whereas gift-giving, as Vogel says, cannot be linked to the interests of shareholders with any ease, sustainability narratives present the company more completely as investor oriented while simultaneously presenting corporate governance and management as morally ordinary. Responsibility is held to simply mean running the company well, treating staff well, obeying the law, and innovating in new markets. And all this is amenable to the company's metrics-generation capacities, whether through external audit or internal control.

More than that, the rise of sustainability narratives acts as a transmission mechanism that seeks to bring corporate conduct and the hierarchies, disciplines, and licences of corporate economy as a whole to society. It seeks to reinforce the myths and conventions through which a broadly neoliberal moral economy is established. As such, sustainability is far more substantial than "greenwash" allegations suggest. It is not the environmental actions arising from sustainability narratives that are most telling - they are often adopted and abandoned in line with business imperatives. Its substance lies in the sustainable business in the round. Sustainable corporate governance itself, by this measure, is not simply the school of social reform for the corporation. In its adherence to duties, to 
satisfaction in work, and to cohesive social relations, corporate governance is held as a school of social reform for society as a whole.

\section{CONCLUSION}

The corporate economy cannot and does not persist on the basis of force. Rather, it persists on the basis of ongoing attempts to define and align the institutions and practices of the corporation and its markets in terms of the broader myths and conventions of moral economy. The corporation - its personhood arising from attempts to provide it with a moral narrative to find its place in programs of social reform - acts to transmit the vicissitudes of economy in moral terms. Sustainability is its most cohesive program yet, bringing together the corporation's disciplinary mechanisms, its productive capacities, and its hierarchical structures in one broad narrative. When we say that the corporation is the "personification of capital," we should see it as the moral voice of capitalism-an articulation, like it or not, of capitalism's virtues.

That said, we should also see the company's moral life as concerned with being the "proper object of love."101 The moral life of the corporation cannot be entirely cast free from questions of moral economy and the broader moral life of society. While sustainability narratives reflect and reinforce the dominance of market norms and the role of the corporation in organizing those norms, we should see the corporation's moral personhood as reflecting a desire to fit in. In this at least, perhaps the corporation may be amenable to reform, and corporate responsibility may reattach itself to its radical potential. 